\title{
Valuations of students toward digital transformation to a result of Covid-19 to improve Sustainability in Education.
}

\author{
Carlos Hervás-Gómez ${ }^{1}$,María Dolores Díaz-Noguera ${ }^{2,}$ *, Olga Guijarro-Cordobés ${ }^{3}$ and Julia \\ Gallardo-Pérez ${ }^{4}$ \\ ${ }^{1}$ Department of Didactics and School Organization, Faculty of Education, University of Seville, 41013 Seville, \\ Spain; hervas@us.es \\ 2 Department of Didactics and School Organization, Faculty of Education, University of Seville, 41013 Seville, \\ Spain; noguera@us.es \\ ${ }^{3}$ Osuna University School, University of Seville, 41640 - Osuna (Sevilla); olgagc@euosuna.org \\ ${ }^{4}$ Department of Financial Economics, Accounting and Operations Management, University of Huelva, Spain; \\ julia.gallardo@uhu.es \\ * Correspondence: hervas@us.es
}

\begin{abstract}
The management of a cultural change in higher education is becoming necessary and unavoidable: changes in teaching, changes in research and changes in governance. Digital transformation is an essential part of many countries' modernisation agendas. The aim of this nonexperimental, descriptive, survey-based study was to explore the perceptions of university students toward the digital transformation that took place in university teaching as a consequence of COVID19. The specific objectives proposed were to: a) analyse the perceptions of students toward digital transformation in university teaching; $b$ ) determine the valuation of students about the digital transformation that occurred in university teaching as a result of COVID-19; and c) explore the resources (hardware-software), professional collaboration, digital pedagogy and student empowerment (motivation) with respect to digital education and the recent changes in university teaching due to the pandemic. The results show that a large number of items are positively correlated. In conclusion, further research should delve into motivation, collaboration, reflective experience sharing, self-learning and initiatives that promote the development of competences in future teachers.
\end{abstract}

Keywords: Digital transformation, active pedagogies, higher education, digitalisation, empowerment, teaching competences.

\section{Introduction}

Digital Transformation (DT) is the main strategy of economic development, and all organisations worldwide are currently adapting to it. Our society was already complex and characterised by the interdependence that was generated among ideology, technology, economy, working environments and globalisation. The management of a cultural change in higher education (HE) is becoming necessary and unavoidable: changes in teaching, changes in research and changes in governance. DT is an essential part of many countries' modernisation agendas. Future research in this line must contemplate, among other aspects: the consequences of SDG 4 in the DT of HE by regions, countries or continents; the opportunities and challenges generated by Blockchain in the educational context; the corporate vulnerability of digital threats; the link between artificial intelligence and sustainable development; the role of HE in the scope of DT; cybersecurity in HE; the future of HE in Industry 4.0; and the analysis of disruptive Blockchain projects. 
In our case, the 2030 Agenda guides the way that links DT to the Sustainable Development Goals (SDG). It is stated that the rise of information and communication technologies (ICT) involves a considerable potential to accelerate progress, reduce the digital divide and promote the development of inclusive knowledge societies based on human rights, empowerment and the attainment of gender equality. The development of inclusive knowledge societies must be based on four pillars: freedom of speech, freedom of information, universal access to information and knowledge, and quality learning [1].

In this sense, the emergence of new organisational structures is creating a new institutional culture that enables DT. The literature shows that the companies that do not approach DT will disappear in several years, and that the success of change projects lies in a cultural transformation. Similarly, in education, specifically in higher education, DT is taking place. Initially, this change was associated with the application of digital technologies, which has continued to advance with the socalled "digital pedagogies", digital literacy, the European Framework for the Digital Competence of Educators, the importance of the coordination between the planning and projects that regulate the life of educational centers and the simultaneous incorporation of their digital project. In agreement with the rest of social organisations, DT is the change associated with the application of digital technologies in all aspects of human society $[2,3]$.

The UNESCO has created the ICT Competence Framework for Teachers (ICT-CFT), which is a tool to guide the initial and permanent training of educators in the use of ICT in the entire education system. The ICT-CFT has been designed to adapt to the national and institutional objectives, thus providing an updated framework for professional development and the creation of policies. ICT-CFT version 3 responds to the recent technological and pedagogical evolution in the field of ICT and education, and it incorporates the inclusive principles of non-discrimination, open and equitable access to information and gender equality, by teaching with the help of technologies. This tool also addresses the implications of the recent technological advances in education and learning, such as: artificial intelligence (AI), mobile technologies, the Internet of Things and open educational resources, with the aim of supporting the creation of inclusive knowledge societies.

The process of DT requires technology, digital culture and leadership in order to be fully accepted in the educational environments. One of the digital enablers is the hybridisation between the physical and digital worlds; in our case, this situation is reflected in the multimodal models of face-to-face and distance learning. We need certain leadership profiles that will undoubtedly be essential for an efficient management focused on the well-being of the people. That is, we need positive leaders [ $\left.{ }^{4}\right]$ to work on the change and development of educational organisation; this has been successfully achieved by many management teams in their educational centres, and now they must advance in these aspects with confidence. All the studies found in the literature about the organisations that have overcome situations of maximum stress and internal destructuring state that promoting positive emotions improves the motivation and well-being of professionals, which in turn increases their creativity, commitment and capacity to adapt to new situations. Successful managers who lead these resilience processes have focused on "what works", "the critical factors of success" of the new organisation and "the positive aspects" of each collaborator as a starting point of improvement. The factors that are being studied nowadays $[5,6,7]$ have identified the following factors as descriptors that define a positive leadership model: involvement, innovation, influence, resilience and coaching.

DT is directly involved in the new types of innovation and creativity in HE. Similarly, the traditional teaching methods have been improved and supported. In the present time of the pandemic, digitalisation has allowed developing efficient academic actions when the situation did not allow attending face-to-face lectures. The aim is not to follow a fashion technological trend but much more, since DT brings accessibility to vulnerable groups and improves the efficacy of educational methodologies, which provides the educational quality that we have been searching for so long. Fundamentally, DT is the reinvention of educational organisations.

\subsection{Rethinking Higher Education.}


The future is decreasingly based on the past. We are not in crisis, but we have advanced to a new age. We are in the Age of Innovation. To understand the nature of this new age, one must only check the literature about the impact of change [ $\left.{ }^{8}\right]$. We will have to reinvent education and the concept of organisation, since DT will modify the educational scenarios as we know them. What is needed for this transformation? The DT of an organisation requires incorporating technologies, creating or modifying processes and employing people with the adequate capacities and skills for such processes and technologies.

In these working keys there are studies aimed at identifying the degree of integration of technology in the organisational structures of educational centres [ $\left.{ }^{9}\right]$. The following resistances have been found among teachers: fear of technology, fear of the change involved in the incorporation of technologies and active methodologies, the change of the teacher's role, and the detection of a positive leadership that amplifies the DT processes. Regarding the barriers, these are related to resources, such as the lack of available devices for teachers and students mentioned in the abovementioned study. With respect to organisational structure, the path is marked by closed hierarchical innovation; innovation is collective intelligence. This situation is revisable with the forced incorporation of digitalisation in educational centres.

Therefore, the attitude of teachers is a key element for e-organisation, as it is also for future teachers. Studies conducted in other countries show that pedagogy and emerging technologies must be incorporated in future teacher training plans $\left.{ }^{10}\right]$. Other studies have designed an explanatory theoretical model $\left.{ }^{[1}\right]$ with four teacher profiles in terms of the use of technologies in the classroom: "reluctant", "learner", "manager" and "e-innovator". These studies state that, in order to develop these attitudes we seek for future teachers, it is essential to promote self-confidence and the collaboration of the educational community.

\subsection{Digital active pedagogies.}

Rethinking the curriculum and learning ecologies, as an analytical framework to determine how we learn and what contexts we need, is a relevant strategy for learning $\left[{ }^{12},{ }^{13}\right]$. Future teachers under training are facing an unprecedented and unknown situation. On the bright side, they have the chance to experiment and "live" virtual teaching in all its dimensions. Similarly, they are given the opportunity to observe, design and evaluate innovating projects in their professional practice. The acceleration of training in all educational levels has been considerable. We cannot disregard the relevance of the development of Personal Learning Environments (PLEs). PLEs have become essential experiences during the pandemic. Studies focused on recognising the different types of learning that can be acquired by our future teachers are aimed at unraveling and delving into the possibilities of Learning Ecologies (LE) in the institutional, business and working reality of their social environment, in a pandemic such as the one caused by COVID-19. Other studies are aimed at critically analysing the new learning environments as dynamic and informal environments, as well as developing the capacity of future teachers to be autonomous in the execution of tasks that require the application of theory and practice.

\subsection{The empowerment of future teachers.}

Other studies related to LE show that technological resources can provide great help in the learning and professional development processes. The increasing impact of LE is a framework to interpret and explore the multiple opportunities for digital learning [ $\left.{ }^{12}\right]$. Previous investigations have demonstrated the importance of PLEs in HE and in the professional development of future educators [14].

Social projection used to be carried out in a world characterised by promptness and immediacy, where working environments were in constant development and alert for the quickly changing demands. What happened to us now? Why has it been of utmost importance to face confinement and bring the school to our homes? The coronavirus, which has changed the customs of most of humanity drastically and very quickly, has taken to the extreme the management of the new economic and social paradigm focused on the development of competences. After this experience, we have learned 
to work, study and socialise in a different way. We miss human contact, which is so important for learning and communication. To date, many of our teaching-learning procedures were based on time shifts, and through the lockdown experience we can help to transform such system toward tasks.

Social projection is found in the new challenges of the working environments that are in constant crisis management (health, economic and social crises), which must thereby be very sensitive to the demands of the development agendas, such as those included in the abovementioned 2030 Agenda (green energy, telecommunications and digitalization). It seems that long time ago, when researchers wrote about knowledge generation, learning was considered ubiquitous $\left[{ }^{15}\right]$, invisible $\left[{ }^{16}\right]$, connected $\left[17,{ }^{18}\right]$ and rhizomatic $\left[{ }^{19}\right]$, as new formats were created, and times and spaces were expanded and modified. Future teachers will have to respond to a set of emerging skills and competences. This requires leadership in their own working life, responsibility in their own development and selfmanagement of their intentional learning projects inside and outside formal institutional environments.

Anyone who wants to carry out a project of intentional learning would generally ask him/herself: what do I want to achieve and how can I do this? What are the human and material resources that are available in the course of the project? Which are the most suitable and efficient instruments to carry out the activities and support my project? What is the expected result and how can I know that the objectives have been met? This idea is key in the change of institutional culture that must be sought in higher education.

The creation of challenging situations for students in terms of self-management in a formal institutional framework is wide. Two example of this are: learner control as an expression of selfmanagement and learner control from the perspective of instructional control. The student must make independent decisions on what and how to learn $\left[{ }^{20}\right]$, although not by him/herself; there must be a balance between learner control and the facilitator role played by the educator. This new professional role must be characterised by negotiation and the exchange of perspectives, ensuring the necessary resources and validating the results of training in digital competences, emerging technologies, digital learning (gamification), digital evaluation and empowerment for the participation of students in LE. All these scopes constitute a relevant part of university training in all fields of knowledge.

The existence of a team that provides help and support to face technical difficulties is important. Through e-learning as the centre of teaching interest, a methodology based on problems, projects and working contracts has been introduced. The new learning model is based on continuous learning, and it results in the combination of different learning contexts, which include formal, non-formal and informal learning. These emerging circumstances have been analysed in studies on ubiquitous learning, continuous learning and expanded education contexts. The creation of "learning ecologies for continuous learning" provides an integrated conceptualisation of learning as a complex phenomenon that unites formal, non-formal and informal learning experiences. This creation offers a framework to understand how individuals select, experiment, navigate and participate in learning experiences that comprise multiple contexts [ $\left.{ }^{21}\right]$.

We have revised and verified the impact of learning styles on future leadership models. The attitudes toward computer technology are key, as well as the design and creation of materials. It is important to take into account the relationship between interests and skills in order to choose the most adequate education and evaluate its strategies. One of the implications that we detected is related to the motivation that students have experienced and expressed in the design of their materials. These smart classroom studies show that intelligent technology is aiding the development of inquiry, collaborative, group, mobile and ubiquitous learning [ $\left.{ }^{22}\right]$. The smart classroom can adapt in a personalised manner to the individual learning of each student. It enriches learning, by supporting it with interactive resources provided by emerging technologies, such as Augmented Reality (AR) $\left[{ }^{23},{ }^{24}, 25\right]$. In a smart classroom environment it is easier to stimulate the motivation of students for learning, promote their active learning and achieve an adequate learning performance [26]. Thus, $\left.{ }^{27}\right]$ proposed the development and promotion of an active learning environment in smart schools of Malaysia. In this process, multimedia technology and Web 2.0 tool, specifically 
MyPortfolio, were integrated to allow students to learn on their own and to record their evolution and experiences within this cooperative learning environment.

The obtained results show the valuation of the following aspects: motivation, collaboration and reflective exchange of experiences, self-learning, promotion of initiatives and decision making. The tasks they promote facilitate the development of competences associated with the search of information, planning, reflection, coordination, cooperation, professional development and leadership.

The professional development of faculty members is a key factor to guarantee a good higher education $\left[{ }^{28},{ }^{29}\right]$. The concept of PLE has been interpreted in different ways [ $\left.{ }^{30}\right]$. The main benefit of PLEs is related to the opportunities offered to students to control their environment, expanding beyond the physical space of educational institutions [ $\left.{ }^{31}\right]$. As was pointed out by [32], learning is becoming increasingly self-directed and informal thanks to technology, hence the need to explore what resources are used by teachers to promote their professional development from the integrating perspective provided by LEs. This way of learning is a revolution in permanent teacher training, since teachers lead and control their own learning and they are able to identify their needs, interests and potentialities. These aspects are very significant indicators of teacher professional development $[33,34]$.

Digital citizenship, i.e., the competences and ethical values required to participate in on-line society, is an increasingly essential element in the $21^{\text {st }}$ century. Critical thinking [ ${ }^{35}$ ], citizenry [ ${ }^{36}$ ] and the inclusion of systems like interactive groups, collaborative learning and peer tutoring have proved to be efficient strategies that help all students to reach their maximum potential based on their learning capacities, while they also promote social inclusion and the coexistence of the entire classroom and community [ $\left.{ }^{37}\right]$.

\subsection{Competences of the future teacher.}

The professional profile of the teacher in the digital age is defined by a combination of knowledge, skills and attitudes required for the responsible use of digital resources in the university context. It is important to highlight the impact of using the didactic and pedagogical principles that facilitate the integration of this new educational paradigm. Digital competence frameworks for teachers have been legislated in Europe, such as DigCompEdu, which was published in 2017. This framework establishes the skills and digital competences of teachers, at all levels. It shows six working areas:

- Area 1: professional environment (organisational communication, professional collaboration, reflective practice and continuous digital professional development).

- Area 2: digital resources (select, create, modify, administrate, protect and share).

- Area 3: digital pedagogy (management and organisation of the use of tools in teaching and learning; guidelines, collaborative learning and self-managed learning).

- Area 4: evaluation and feedback (evaluation strategies and test analyses; feedback and planning).

- Area 5: student empowerment, accessibility and inclusion, differentiation and personalisation; active student participation.

- Area 6: facilitation of the digital competence of students and 22 specific competences.

Other studies are based on needs analysis $\left[{ }^{10}\right]$.

Future teachers will have to use digital resources as a guide to acquire competences related to digital society, such as critical and innovative reflection, solving complex problems, collaborative capacity and socioemocional attitudes.

This pandemic has shown that teachers must be deemed competent in the digital field. Research has been extensive in this scope in the last decades. The irruption of technological resources in all education levels has disrupted the education system [ $\left.{ }^{38}\right]$. Universities are transforming and international institutions are adopting competence frameworks such as the Digital Competence Framework for Educators (DigCompEdu). Some studies show the successful implementation of the frameworks $\left[{ }^{39}\right]$. 


\section{Materials and Methods}

Method: This was a non-experimental, descriptive study based on surveys [ $\left.{ }^{40}\right]$. The aim of this study was to explore the perceptions of university students toward the digital transformation in university teaching that took place as a consequence of the COVID-19 pandemic. The specific aims were to: a) analyse the perceptions of university students toward digital transformation in university teaching; b) determine the valuation given by university students about the digital transformation that occurred in university teaching as a result of COVID-19; and c) explore the resources (hardwaresoftware), professional collaboration, digital pedagogy and student empowerment (motivation) with respect to digital education and the recent changes in university teaching due to the pandemic.

The participants were recruited by non-probabilistic sampling, using their accessibility as the main selection criterion.

The sample was constituted by students from Osuna University School, which is ascribed to the Faculty of Education Science of the University of Seville (Spain). In general, they showed similar sociodemographic characteristics, and their ages were mainly between 18 and 25 years (Table 1).

Table 1. Age of the participants.

\begin{tabular}{llllll}
\hline & Frequency & Percentage & Valid Percentage & Cumulative Percentage \\
\hline \multirow{4}{*}{ 18 years } & 96 & 19.8 & 19.8 & 19.8 \\
19 years & 79 & 16.3 & 16.3 & 36.0 \\
20 years & 89 & 18.3 & 18.3 & 54.3 \\
& 21 years & 65 & 13.4 & 13.4 & 67.7 \\
Valid 22 years & 42 & 8.6 & 8.6 & 76.3 \\
& 23 years & 33 & 6.8 & 6.8 & 83.1 \\
& 24 years & 25 & 5.1 & 5.1 & 88.3 \\
& 25 or more years & 57 & 11.7 & 11.7 & 100.0 \\
\hline
\end{tabular}

Instrument: The questionnaire on digital transformation in university teaching that took place due to COVID-19 (UDTQ) was developed from an adaptation of the studies conducted by $\left[{ }^{41},{ }^{42}\right]$. This instrument consisted of 37 items (5 identification items and 32 items about digital transformation), grouped into 5 categories: student profile, resources (hardware-software), professional collaboration, digital pedagogy and student empowerment (motivation).

Regarding the student profile, five questions were included to gather information about the main characteristics: 1) sex, 2) age, 3) degree year, 4) group, and 5) degree. The students answered the rest of the questions in a Likert-scale from 1 (strongly disagree) to 5 (strongly agree).

The categories and the rest of the items of the questionnaire are the following:

1) Resources (hardware-software): the hardware requirements of the subjects may vary and, for some subjects, the will of the students to use their own device appeared already in face-to-face education. However, the inaccessibility of institutional devices can be a serious problem for students without hardware (resources).

6. If I had had the opportunity to use the computers of the faculty/school instead of my own computer, I would have taken that opportunity.

7. My own devices-tools help me to better learn the subjects compared to the ones provided by the faculty/school.

8. My devices-tools met the requirements of the platform.

9. How difficult is it to learn to use the digital environment of the platform?

10. In the future, I would rather use my own resources (devices-tools) than the ones provided by the faculty/school.

2) Professional collaboration: the relationships with the students is an important part of higher education, since these can help to develop social skills and improve their behaviour in their future 
workplace. On-line education can have a negative effect on human relationships and hinders the opportunity of face-to-face interactions.

11. How does on-line education affect your interaction with your classmates? (extremely bad extremely well).

12. How frequently do you ask your classmates for help during on-line teaching?

13. How much help do you seek from other students only for academic purposes?

14. How frequently did your on-line student meetings were focused on academic purposes?

15. How much do you miss being face-to-face (without masks) with your classmates?

16. How important is it for you that the teacher uses the webcam during the lectures?

17. In my opinion, I learn better in face-to-face lectures than in on-line lectures.

18. How important is it for you to interact with the teacher verbally every week?

19. How much does the teacher help you to understand the topics of the subject if you can ask questions during the on-line lecture?

20. Do you prefer on-line lectures in the future?

3) Digital pedagogy: emotion and learning are strongly connected and such relationship affects the academic performance (marks). Emotion influences our attention, memories and rational thinking. However, traditional face-to-face lectures can improve the mental health of students. Measuring the amount of emotional support that students require during virtual lectures is a challenge.

21. How difficult is it to adapt to the situation of on-line theory lectures?

22. How difficult is it to adapt to on-line practical work/activities/assignments?

23. How much did you participate during the on-line lectures?

24. Do you think that on-line education is useful?

25. How much are you enjoying on-line education?

4) Student empowerment (motivation): the students' degree of involvement in their studies. The following statements refer to their motivation and attitudes about on-line lectures.

26. In an on-line lecture, I prefer the material of the subject that really challenges me to learn new things.

27. I think that on-line teaching significantly improves the quality of university teaching.

28. On-line lectures are more boring than face-to-face lectures.

29. If I study adequately, I can learn the material of this subject.

30. I believe that I can use what I learn in this subject for other things.

31. I believe that I will get an excellent mark in this subject.

32. Obtaining a good mark in this subject is the most satisfactory thing for me right now.

33. It is important for me to learn the topics of this subject.

34. When I take exams, I think about the consequences of failing.

35. I am very interested in the contents that I am learning in this subject.

36. I am sure that I can do a great job in the assignments and exams of this subject.

37. I think that the material of this subject is useful to learn.

\section{Results}

Once the questionnaires were collected, the mean scores obtained in each of the items were analysed. Regarding the item "If I had had the opportunity to use the computers of the faculty/school instead of my own computer, I would have taken that opportunity" $\left(\bar{\alpha}=3.43 ; \sigma=1.37 ; \sigma^{2}=1.88\right)$, the participants would have taken the opportunity to use the computers of the faculty/school. However, they consider that their own devices help them to learn the subjects better than the ones provided by the faculty/school $\left(\bar{\alpha}=3.54 ; \sigma=1.17 ; \sigma^{2}=1.37\right)$. This is due to the fact that they also considered that "their devices met the requirements of the platform" $\left(\bar{\alpha}=4.29 ; \sigma=1.01 ; \sigma^{2}=1.02\right)$. Therefore, with respect to the future, students prefer to use their own resources (devices) rather than the ones provided by the faculty/school $\left(\bar{\alpha}=3.30 ; \sigma=1.19 ; \sigma^{2}=1.41\right)$. 
The participants did not find it difficult to learn how to use the digital environment of the platform $\left(\bar{\alpha}=2.441 ; \sigma=0.18 ; \sigma^{2}=1.40\right)$.

Regarding the item "How does on-line education affect your interaction with your classmates? (extremely bad - extremely well)" $\left(\bar{\alpha}=2.15 ; \sigma=1.09 ; \sigma^{2}=1.18\right)$, they consider that on-line learning affects them negatively; in this sense, they ask their classmates for help during on-line education $(\bar{\alpha}$ $=3.36 ; \sigma=1.06 ; \sigma^{2}=1.13$ ).

The extent to which these students seek help from other students only for academic purposes was high $\left(\bar{\alpha}=3.26 ; \sigma=.92 ; \sigma^{2}=0.85\right)$, in line with the following item "how frequently did your on-line student meetings were focused on academic purposes?" $\left(\bar{\alpha}=3.87 ; \sigma=1.12 ; \sigma^{2}=1.26\right)$.

When asked "how much they missed being face-to-face (without masks) with their classmates" $\left(\bar{\alpha}=4.75 ; \sigma=0.70 ; \sigma^{2}=0.49\right)$, they showed an extremely high score in their answers.

In this on-line situation, they consider it very important that the teacher uses the webcam during the lectures $\left(\bar{\alpha}=4.29 ; \sigma=1.08 ; \sigma^{2}=1.18\right)$, since "in their opinion, they learn better in face-to-face lectures than in on-line lectures" ( $\left.\bar{\alpha}=4.40 ; \sigma=1.07 ; \sigma^{2}=1.14\right)$. That is, they prefer face-to-face lectures, and during on-line education they think that the teacher must use a webcam and maintain verbal contact (item 18) $\left(\bar{\alpha}=4.47 ; \sigma=0.80 ; \sigma^{2}=0.63\right)$.

The participants considered, with a high score, that asking questions during on-line lectures helps them to understand the topics of the subject $\left(\bar{\alpha}=4.06 ; \sigma=1.02 ; \sigma^{2}=1.04\right)$, although they do not prefer on-line lectures for the future $\left(\bar{\alpha}=1.93 ; \sigma=0.34 ; \sigma^{2}=1.79\right)$.

Regarding the items "how difficult is it to adapt to the situation of on-line theory lectures" $(\bar{\alpha}=$ 3.50; $\left.\sigma=1.16 ; \sigma^{2}=1.34\right)$ and "how difficult is it to adapt to on-line practical work/activities/assignments? $\left(\bar{\alpha}=3.71 ; \sigma=1.14 ; \sigma^{2}=1.31\right)$, they showed that it was very difficult for them to adapt to both the theory and practical lectures, with a medium level of participation in the on-line lectures $\left(\bar{\alpha}=3.06 ; \sigma=1.15 ; \sigma^{2}=1.33\right)$.

The participants did not find on-line education useful $\left(\bar{\alpha}=2.85 ; \sigma=1.20 ; \sigma^{2}=1.45\right)$, obtaining a low degree of enjoyment $\left(\bar{\alpha}=2.39 ; \sigma=1.10 ; \sigma^{2}=1.21\right)$.

Motivation is fundamental in on-line lectures. In this sense, "they prefer the material of the subject that really challenges them to learn new things" $\left(\bar{\alpha}=3.71 ; \sigma=0.91 ; \sigma^{2}=0.83\right)$. Moreover, they do not think that on-line education significantly improves the quality of university teaching $(\bar{\alpha}=2.07$; $\sigma=1.15 ; \sigma^{2}=1.33$.

The participants considered, with a high score, that "on-line lectures are more boring than faceto-face lectures" $\left(\bar{\alpha}=4.09 ; \sigma=1.26 ; \sigma^{2}=1.59\right)$, although they also believed that "if they studied adequately, they could learn the material of that subject" $\left(\bar{\alpha}=4.09 ; \sigma=0.92 ; \sigma^{2}=0.85\right)$. Likewise, "they believed that they could use what they learn in that subject for other things" $\left(\bar{\alpha}=3.85 ; \sigma=0.96 ; \sigma^{2}=\right.$ 0.92). They were very motivated, as they "thought that they would get an excellent mark in that subject" $\left(\bar{\alpha}=3.36 ; \sigma=0.87 ; \sigma^{2}=0.76\right)$; they even considered that "obtaining a good mark in that subject was the most satisfactory thing for them at that time" $\left(\bar{\alpha}=4.17 ; \sigma=0.95 ; \sigma^{2}=0.90\right)$.

Furthermore, the participants responded with high scores to the following items: "it is important for me to learn the topics of this subject" $\left(\bar{\alpha}=4.34 ; \sigma=0.81 ; \sigma^{2}=0.65\right)$; "when I take exams, I think about the consequences of failing" ( $\left.\bar{\alpha}=4.38 ; \sigma=0.94 ; \sigma^{2}=0.87\right)$; "I am very interested in the contents that I am learning in this subject" ( $\left.\bar{\alpha}=4.30 ; \sigma=0.76 ; \sigma^{2}=0.58\right)$; "I am sure that I can do a great job in the assignments and exams of this subject" $\left(\bar{\alpha}=4.00 ; \sigma=0.87 ; \sigma^{2}=0.76\right)$ and "I think that the material of this subject is useful to learn" ( $\left.\bar{\alpha}=4.08 ; \sigma=0.83 ; \sigma^{2}=0.69\right)$.

Regarding the correlational tests, a positive two-sided correlation was detected between resources (hardware-software) and digital pedagogy, with a significance levels of $0.007<0.01$. That is, at high values in the items related to resources (hardware-software), the values of digital pedagogy were also high.

There was also a positive two-sided correlation between resources (hardware-software) and student empowerment (motivation), with a significance level of $0.005<0.01$. That is, if resources increase (hardware-software), student empowerment (motivation) also increases, and vice versa. 
Similarly, there was a positive two-sided correlation between professional collaboration and digital pedagogy, with a significance level of $0.000<0.01$, i.e., the greater the professional collaboration, the greater the values in the items about digital pedagogy.

Another positive two-sided correlation was identified between professional collaboration and student empowerment (motivation), with a significance level of $0.000<0.01$. That is, at high values of professional collaboration, the values of student empowerment (motivation were also high).

Lastly, there was also a positive two-sided correlation between digital pedagogy and student empowerment (motivation), with a significance level of $0.000<0.01$. That is, the greater the values in digital pedagogy, the greater the values in student empowerment (motivation), and vice versa.

After the correlational analysis, we wanted to verify whether the data were significant based on sex. To perform the T-tests, the data had to show normal distribution, which was determined through the Kolmogorov-Smirnov (Ks) test, establishing a significance level of 0.05 (above this value, the distribution was considered normal). In our case, the distribution was normal (0.313). Table 2 shows that the mean of the values of the participants was 3.5068, with a standard deviation of 0.28057 .

Table 2. Kolmogorov-Smirnov (Ks) test.

\begin{tabular}{lll}
\hline Test Statistics & & Average \\
\hline \multirow{3}{*}{ Normal parameters } & Mean & 3.5068 \\
& Standard & 0.28057 \\
& deviation & \\
& Absolute & 0.044 \\
Maximum extreme differences & Positive & 0.028 \\
& Negative & -0.044 \\
Kolmogorov-Smirnov Z & & 0.962 \\
Asymptotic Sig (bilateral) & & 0.313 \\
\hline
\end{tabular}

Once we knew that the distribution was normal, we applied the T-test for independent samples (Table 3).

Table 3. T-test for independent samples.

\begin{tabular}{|c|c|c|c|c|c|c|c|c|c|c|}
\hline & \multicolumn{3}{|c|}{$\begin{array}{l}\text { Equality of } \\
\text { Variances }\end{array}$} & \multicolumn{7}{|c|}{ T-test for Equality of Means } \\
\hline & \multirow[t]{2}{*}{$\mathrm{F}$} & \multirow[t]{2}{*}{ Sig. } & \multirow{2}{*}{\multicolumn{2}{|c|}{$\mathrm{t}$}} & \multirow[t]{2}{*}{$\mathrm{gl}$} & \multirow{2}{*}{$\begin{array}{l}\text { Sig. } \\
\text { (bil.) }\end{array}$} & \multirow{2}{*}{$\begin{array}{l}\text { Mean } \\
\text { Difference }\end{array}$} & \multirow{2}{*}{$\begin{array}{l}\text { Std. Error } \\
\text { Difference }\end{array}$} & \multicolumn{2}{|c|}{$\begin{array}{l}95 \% \text { Confidence Interval of } \\
\text { the Difference }\end{array}$} \\
\hline & & & & & & & & & Lower & Upper \\
\hline $\begin{array}{l}\text { Equal variances } \\
\text { assumed }\end{array}$ & 3.240 & 0.073 & & 3.053 & 484 & 0.002 & 0.08582 & 0.02811 & 0.03058 & 0.14105 \\
\hline $\begin{array}{l}\text { Equal variances } \\
\text { not assumed }\end{array}$ & & & & 2.974 & 233.501 & 0.003 & 0.08582 & 0.02885 & 0.02897 & 0.14266 \\
\hline
\end{tabular}

The Levene's test for equality of variances shows whether we can or cannot assume equal variances. Therefore, if the probability associated with the Levene statistic is $>0.05$, we assume equal variances, and if it is $<0.05$, we assume different variances. In our case, once the data are analysed, we asumme the same variances, since it is above 0.05 .

After assuming equal variances, statistic $t$, with its bilateral significance level, shows the degree of compatibility between the hypothesis of equality of means and the differences between the 
population means. In our case, $t$ was below 0.05 , indicating that there is no compatibility between the hypothesis of equality of means and the differences between the means of the represented groups according to sex. Therefore, there are no significant differences based on gender.

\section{Conclusions}

After the analysis of the questions related to resources (software and hardware), we can assert that most students, with adequate competence in the use of computer equipment, do not find it difficult to adapt to distance teaching. Likewise, in view of the obtained results, we can infer that there is no digital divide among the students of the analysed sample, since they find their devices sufficiently suitable and, thus, they do not require those provided by their educational centres, which is in line with the findings of other studies carried out during the COVID-19 pandemic [ $\left.{ }^{43}\right]$.

In general, the participants of this study consider that they will obtain good results with on-line teaching and are highly motivated with their studies. However, some of them find it difficult to adapt, feel discouraged (they do not like it) and reject this way of learning for the future. Moreover, they highly value interacting with their classmates and teacher in the classroom, as well as physically being in the classroom, which is in agreement with the results of other studies performed all over the world [ $\left.{ }^{44}\right]$.

In this sense, new and interesting research lines emerge. We do not know whether such rejection to remoteness among the protagonists of the teaching and learning processes is due to the novelty of this situation, the imposed lockdown to fight the pandemic or the change experienced in the months of confinement, which coincided with the beginning of this model of virtual teaching. Could this opinion evolve in time with the normalisation of the health and social situation of the students? Is this valuation negatively influenced by the stress that the students have suffered during the lockdown? Were the lectures suitable to the demands of on-line teaching, or were the design and implementation of the lectures not up to the task? Are we living a DT accelerated by the current circumstances, in which there was not enough time to create the necessary pedagogical structures to implement a quality education? All these questions pave the road for new research lines that could help to improve DT in the field of education.

We should not forget the importance of knowing the interest of students in DT in certain educational scopes. They may not like the idea of distance learning, globally, but that does not imply that they reject any type of virtual learning (courses, assignments, specific contents...). This requires the conceptual and philosophical reevaluation of teaching and learning, as well as of the roles of teachers, students and didactic materials and the connections between them [45].

Therefore, there could be a direct relationship between DT and the new types of innovation and creativity in higher education. Similarly, the traditional teaching methods are improved and supported. During this pandemic, digitalisation has provided us with the possibility of developing efficient academic actions when attending the classrooms was not possible. The aim is not to follow a fashion technological trend but much more, since DT brings accessibility to vulnerable groups and improves the efficacy of educational methodologies, which provides the educational quality that we have been searching for so long. Fundamentally, DT is the reinvention of educational organisations.

Author Contributions: Investigation, Ma.D.D-N., C.H.-G., O.G-C. and M‥ Á.D.-G. All authors have read and agreed to the published version of the manuscript.

Acknowledgments: This article is part of the research project entitled: Design, production and evaluation of tMOOC for the acquisition of digital competences of university teaching staff, (reference US-1260616). $\mathrm{R}+\mathrm{D}+\mathrm{i}$ projects FEDER Andalucía 2014-2020 (https://investigacion.us.es/sisius/sis_proyecto.php?idproy=30423) The authors are grateful for the collaboration of the Osuna University School of the University of Seville for the collection of research data. The authors also thank the Didactic Research Group (GID): Technological and Qualitative Analysis (code: HUM-0390, Education Office of the Government of Andalusia, Spain). 
Conflicts of Interest: The authors declare no conflict of interest.

\section{References}

(1) OECD. OECD Multilingual Summaries TALIS 2018 Results (Volume II). Teachers and School Leaders as Valued Professionals Resultados de TALIS 2018 (Volumen II). Profesores y Responsables de Centros Educativos Como Profesionales Valorados.; OECD, 2020; Vol. II.

(2) Kreiling, L.; Serval, S.; Bounfour, A. The Influence of Territorial Anchoring on Technology Transfer Organisations in Regional Innovation Systems: Towards a Paradox between Economic and Territorial Values? In 6e Colloque de l'Association Internationale de Recherche en Management Public (AIRMAP) -Un Management Public Universel ?; 2017.

(3) Seresco. Habilitadores digitales: las herramientas de la Industria 4.0 https://industria4.es/formacion/habilitadores-digitales-herramientas-industria-4/ (accessed Dec 6, 2020).

(4) Álvarez-Álvarez, C.; Fernández Gutiérrez, E. Assessment of School Principals in Spain: Lights $\begin{array}{llllll}\text { and Shadows. } & \text { 2020, } & \text { 25resorado } 269 .\end{array}$ https://doi.org/10.30827/PROFESORADO.V24I2.14077.

(5) Tintoré, M.; Cantón-Mayo, I.; Quiroga, M.; Parés, I. Liderazgo y E-Liderazgo En Las Historias de Vida de Líderes Educativos a Través Del Mundo. Edmetic, Rev. Educ. Mediática y TIC 2019, 8 (2), 17-36. https://doi.org/10.21071/edmetic.v8i2.11700.

(6) Villa-Sánchez, A. Leadership: A Key to Innovation and Educational Change. Rev. Investig. Educ. 2019, 37 (2), 301-326. https://doi.org/10.6018/rie.37.2.365461.

(7) Weinstein, J.; Muñoz, G.; Flessa, J. Liderazgo Directivo Para La Calidad de La Educación: Aprendizajes Desde Un Campo de Investigación Emergente. Calid. en la Educ. 2019, No. 51, 10-14. https://doi.org/10.31619/caledu.n51.793.

(8) Kurzweil, R. La era de las máquinas espirituales https://doku.pub/download/1999-la-era-delas-maquinas-espirituales-z06w2zoknjqx (accessed Dec 6, 2020).

(9) Area Moreira, M.; Santana Bonilla, P. J.; Sanabria Mesa, A. . La Transformación Digital de Los Centros Escolares. Obstáculos y Resistencias. The Digital Transformation of Schools . Obstacles and Resistances. Digit. Educ. Rev. 2020, No. 37, 15-31.

(10) Zotikovna Vlasova, E.; Viktorovna Goncharova, S.; Polikarpovich Barakhsanov, V.; Alekseevna Ivanova, E.; Aleksandrovna Karpova, N.; Sergeevna Ilina, T.; Stepanovna Sysoeva, A. Digital Transformation of the Pedagogical Education in the Russian Federation. Rev. Dilemas Contemp. Educ. Política y Valores 2019, 7 (52), 1-121.

(11) Sosa Díaz, M. J.; Valverde Berrocoso, J. Perfiles Docentes En El Contexto de La Transformación Digital de La Escuela. Bordon. Rev. Pedagog. 2020, 72 (1), 151-173. https://doi.org/10.13042/Bordon.2020.72965.

(12) González-Sanmamed, M.; Estévez, I.; Souto-Seijo, A.; Muñoz-Carril, P.-C. Ecologías Digitales de Aprendizaje y Desarrollo Profesional Del Docente Universitario I Digital Learning Ecologies and Professional Development of University Professors. Comunicar 2020, 28 (62), 918.

(13) Hervás-Gómez, C.; Díaz-Noguera, Ma. Dolores Domínguez-González, M. Á.; Reina-Parrado, M. Un Entorno Participativo y Colaborativo: El Aula Inteligente En La Enseñanza Universitaria. In Innovación docente en la universidad y realidades emergentes; Octaedro, Ed.; Octaedro: Barcelona, 2020; pp 191-209. 
(14) Díaz Noguera, M. D.; Álvarez Arregui, E.; Rodríguez Martín, A. Ecosistemas de Formación Autónomos En El Desarrollo Profesional Del Pedagogo. Ecosystems Autonomous Training of Teacher Profesional Development. Pixel-Bit Rev. Medios y Educ. 2013, No. 43, 99-112. https://doi.org/10.12795/pixelbit.2013.i43.05.

(15) Díez-Gutiérrez, E.; Díaz-Nafría, J. Ecologías de Aprendizaje Ubicuo Para La Ciberciudadanía Crítica. Comunicar 2018, No. 54, 49-58.

(16) Cobo, C.; Moravec, J. W. Aprendizaje Invisible. Hacia Una Nueva Ecología de La Educación; 2011.

(17) Teixeira Witt, D.; Martini Rostirola, S. C. Conectivismo Pedagógico: Novas Formas de Ensinar e Aprender No Século XXI. Rev. Thema 2020, 16 (4), 1012-1025. https://doi.org/10.15536/thema.v16.2019.1012-1025.1583.

(18) Siemens, G. Conectivismo: uma teoria da aprendizagem para a era digital http://humana.social/conectivismo-una-teoria-da-aprendizagem-para-a-era-digital/ (accessed Dec 6, 2020).

(19) Cormier, D. Rhizomatic Education: Community as Curriculum. Innov. J. Online Educ. 2008, 4 (5).

(20) Drachsler, H.; Pecceu, D.; Arts, T.; Hutten, E.; Rutledge, L.; Van Rosmalen, P.; Hummel, H.; Koper, R. ReMashed - Recommendations for Mash-up Personal Learning Environments. Lect. Notes Comput. Sci. 2009, 5794, 788-793. https://doi.org/10.1007/978-3-642-04636-0_85.

(21) Sangrà, A.; Raffaghelli, J. E.; Veletsianos, G. Lifelong Learning Ecologies: Linking Formal and Informal Contexts of Learning in the Digital Era. Br. J. Educ. Technol. 2019, 50 (4), 1615-1618. https://doi.org/10.1111/bjet.12828.

(22) Lin, Y.-T.; Huang, Y.-M.; Cheng, S.-C. An Automatic Group Composition System for Composing Collaborative Learning Groups Using Enhanced Particle Swarm Optimization. Comput. Educ. 2010, 55 (4), 1483-1493. https://doi.org/10.1016/j.compedu.2010.06.014.

(23) Restivo, T.; Chouzal, F.; Rodrigues, J.; Menezes, P.; Bernardino Lopes, J. Augmented Reality to Improve STEM Motivation. In 2014 IEEE Global Engineering Education Conference (EDUCON); IEEE, 2014; pp 803-806. https://doi.org/10.1109/EDUCON.2014.6826187.

(24) Silva, J. F.; Restivo, F. J. An Intelligent Mashup Learning Environment with Social Interaction. In 8th European Conference on eLearning 2009, ECEL 2009; 2009; pp 759-766.

(25) Yang, J. C.; Lin, Y. L. International Forum of Educational Technology \& Society Development and Evaluation of an Interactive Mobile Learning Environment with Shared Display Groupware. Int. Forum Educ. Technol. Soc. 2016, 13 (1), 195-207.

(26) Liu, M.; Horton, L.; Olmanson, J.; Toprac, P. A Study of Learning and Motivation in a New Media Enriched Environment for Middle School Science. Educ. Technol. Res. Dev. 2011, 59 (2), 249-265. https://doi.org/10.1007/s11423-011-9192-7.

(27) Or Kan, S. Cooperative Learning Environment with the Web 2.0 Tool E-Portfolios. Turkish Online J. Distance Educ. 2011, 12 (3), 201-214.

(28) Darling-Hammond, L.; Richardson, N. Teacher Learning: What Matters? Educ. Leadersh. 2009, 66 (5), 46-53.

(29) Inamorato Dos Santos, A.; Gausas, S.; Mackeviciute, R.; Jotautyte, A.; Martinaitis, Ž. Innovating Professional Development in Higher Education: An Analysis of Practices, EUR 29676; Publications Office of the European Union, Luxembourg, 2019. https://doi.org/10.2760/26224.

(30) Attwell, G. Personal Learning Environments - the Future of ELearning ? eLearning Pap. 2007, 
$2(1), 1-8$.

(31) Cabero-Almenara, J.; Llorente-Cejudo, C.; Marín, V. Hacia El Diseño de Un Instrumento de Diagnóstico de “Competencias Tecnológicas Del Profesorado" Universitario. Rev. Iberoam. Educ. 2010, 52, 1-12.

(32) He, T.; Li, S. A Comparative Study of Digital Informal Learning: The Effects of Digital Competence and Technology Expectancy. Br. J. Educ. Technol. 2019, 50 (4), 1744-1758. https://doi.org/10.1111/bjet.12778.

(33) Muijs, D.; Day, C.; Harris, A.; Lindsay, G. 12 Evaluating CPD : An Overview. In International handbook of continuing professional development of teachers.; McGraw-Hill Education: Berkshire, 2005; pp 291-319.

(34) Yurkofsky, M. M.; Blum-Smith, S.; Brennan, K. Expanding Outcomes: Exploring Varied Conceptions of Teacher Learning in an Online Professional Development Experience. Teach. Teach. Educ. 2019, 82, 1-13. https://doi.org/10.1016/j.tate.2019.03.002.

(35) Delgado-Algarra, E. J.; Aguaded, I.; Bernal-Bravo, C.; Lorca-Marín, A. A. Citizenship and Pluriculturalism Approaches of Teachers in the Hispanic and Japanese Contexts: Higher Education Research. Sustainability 2020, 12 (8), 1-20. https://doi.org/10.3390/SU12083109.

(36) Thorson, K. What Does It Mean to Be a Good Citizen? Citizenship Vocabularies as Resources for Action. Ann. Am. Acad. Pol. Soc. Sci. 2012, 644 (1), $70-85$. https://doi.org/10.1177/0002716212453264.

(37) Glatzel, G. A. Clases Diversas En Las Escuelas de Estados Unidos. La Importancia de Una Educación Inclusiva. Rev. Nac. e Int. Educ. Inclusiva 2017, 10 (2), 79-98.

(38) Farnós Miró, J. D. La educación disruptiva: tratado y compendio https://juandomingofarnos.wordpress.com/2019/10/09/educacion-disruptiva-tratado-ycompedio/ (accessed Dec 6, 2020).

(39) Cabero-Almenara, J.; Barroso-Osuna, J.; Palacios-Rodríguez, A.; Llorente-Cejudo, C. Digital Competency Frames for University Teachers: Evaluation through the Expert Competence Coefficient. Rev. Electron. Interuniv. Form. del Profr. 2020, 23 (3), 17-34. https://doi.org/10.6018/reifop.413601.

(40) Fowler, F. J. The Problem with Survey Research. Contemp. Sociol. A J. Rev. 2014, 43 (5), 660662. https://doi.org/10.1177/0094306114545742f.

(41) Bogdandy, B.; Tamas, J.; Toth, Z. Digital Transformation in Education during COVID-19: A Case Study. In 11th IEEE International Conference on Cognitive Infocommunications - CogInfoCom 2020; 2020; pp 173-178. https://doi.org/10.1109/coginfocom50765.2020.9237840.

(42) Pintrich, P. R.; Smith, D. A. F.; Garcia, T.; McKeachie, W. J. A Manual for the Use of the Motivated Strategies for Learning Questionnaire (MSLQ); Michigan State University, United States, 1991.

(43) García-Aretio, L. COVID-19 y Educación a Distancia Digital: Preconfinamiento, Confinamiento y Posconfinamiento. RIED. Rev. Iberoam. Educ. a Distancia 2021, 24 (1), 9-32. https://doi.org/10.5944/ried.24.1.28080.

(44) World Bank. How countries are using edtech (including online learning, radio, television, texting) to support access to remote learning during the COVID-19 pandemic https://www.worldbank.org/en/topic/edutech/brief/how-countries-are-using-edtech-tosupport-remote-learning-during-the-covid-19-pandemic (accessed Dec 6, 2020).

(45) Jandrić, P.; Knox, J.; Besley, T.; Ryberg, T.; Suoranta, J.; Hayes, S. Postdigital Science and 
Education. Educ. Philos. Theory 2018, $50 \quad$ (10), 893-899. https://doi.org/10.1080/00131857.2018.1454000. 